\title{
A highly concentrated diet increases biogas production and the agronomic value of young bull's manure
}

\author{
Mônica Sarolli Silva de Mendonça Costa ${ }^{\mathrm{a}, *}$, Jorge de Lucas Jr. ${ }^{\mathrm{b}}$, Luiz Antonio de Mendonça Costa ${ }^{\mathrm{a}}$, \\ Ana Carolina Amorim Orrico ${ }^{c}$ \\ ${ }^{a}$ Research Group on Water Resources and Environmental Sanitation, Western Parana State University, Agricultural Engineering Graduate Program, Rua Universitária, \\ Jardim Universitário, 2069, 85.819-110 Cascavel, Paraná, Brazil \\ ${ }^{\mathrm{b}}$ Department of Rural Engineering, São Paulo State University, College of Agricultural and Veterinary Sciences at Jaboticabal, São Paulo, Brazil \\ ${ }^{\mathrm{c}}$ College of Agricultural Sciences, Federal University of Grande Dourados (UFGD), Dourados, MS, Brazil
}

\section{A R T I C L E I N F O}

\section{Article history:}

Received 23 April 2015

Revised 18 September 2015

Accepted 26 September 2015

Available online 10 December 2015

\section{Keywords:}

Temperature

Inoculum

Semi-continuous

Digestate

\begin{abstract}
A B S T R A C T
The increasing demand for animal protein has driven significant changes in cattle breeding systems, mainly in feedlots, with the use of young bulls fed on diets richer in concentrate (C) than in forage (F). These changes are likely to affect animal manure, demanding re-evaluation of the biogas production per $\mathrm{kg}$ of TS and VS added, as well as of its agronomic value as a biofertilizer, after anaerobic digestion. Here, we determined the biogas production and agronomic value (i.e., the macronutrient concentration in the final biofertilizer) of the manure of young bulls fed on diets with more $(80 \% \mathrm{C}+20 \% \mathrm{~F}$; 'HighC' diet) or less $\left(65 \% \mathrm{C}+35 \% \mathrm{~F}\right.$; 'LowC' diet) concentrate, evaluating the effects of temperature $\left(25,35\right.$, and $\left.40^{\circ} \mathrm{C}\right)$ and the use of an inoculum, during anaerobic digestion. A total of 24 benchtop reactors were used, operating in a semi-continuous system, with a 40-day hydraulic retention time (HRT). The manure from animals given the HighC diet had the greatest potential for biogas production, when digested with the use of an inoculum and at 35 or $40{ }^{\circ} \mathrm{C}\left(0.6326\right.$ and $0.6207 \mathrm{~m}^{3}$ biogas $/ \mathrm{kg}$ volatile solids, or VS, respectively). We observed the highest levels of the macronutrients $\mathrm{N}, \mathrm{P}$, and $\mathrm{K}$ in the biofertilizer from the manure of animals given HighC. Our results show that the manure of young bulls achieves its highest potential for biogas production and agronomic value when animals are fed diets richer in concentrate, and that biogas production increases if digestion is performed at higher temperatures, and with the use of an inoculum.
\end{abstract}

(ㄷ) 2015 Elsevier Ltd. All rights reserved.

\section{Introduction}

The anaerobic digestion of cattle manure (generated by animal farming) produces clean energy in the form of biogas, and also converts manure into biofertilizers that can be used for plant nutrition (Cestonaro et al., 2015). Biogas production from cattle manure is highly influenced by manure chemical composition (Orrico et al., 2010). Feeding cattle diets containing high levels of concentrate increases the biogas production from manure, due to the generation of higher levels of soluble organic- $C$ during anaerobic digestion (Orrico et al., 2010, 2012; Costa et al., 2013). Animal nutrition also affects the composition of manure-derived biofertilizers, altering directly the levels of the macronutrients $\mathrm{N}, \mathrm{P}$, and $\mathrm{K}$ (Orrico et al., 2012).

Despite the overwhelming effect of manure chemical composition on biogas production, the latter can also be modulated by

\footnotetext{
* Corresponding author.
}

temperature (Cavinato et al., 2013; Gou et al., 2014; Kinnunen et al., 2014), and by the use of an inoculum (Saidu et al., 2013; Hidalgo and Martín-Marroquín, 2014; Gu et al., 2014), especially in reactors operated in semi-continuous systems.

The increasing demand for animal protein has led to worldwide changes in meat production systems, particularly in intensive farming and industrial settings. Brazilian meat cattle breeding systems have undergone structural and conjunctural adjustments, with increased use of modern agricultural technologies and meat exporting, as well as alterations in herd geographical distribution (Oaigen et al., 2013). These changes enabled a significant expansion of herds toward the Midwest and North, as a response to the competition for agricultural areas in the Southeast and South of Brazil.

Competition for livestock area and the search to improve meat quality have not only intensified feedlot production, but also reduced slaughter age. This is a central aspect of the Brazilian model for raising young bulls, which is characterized by 
confinement of animals after weaning, and slaughter at the early age of 15 months (Silveira, 1995). At this age, animals have a minimum live weight of $450 \mathrm{~kg}$ and a coverage of subcutaneous fat in the upper housing of $4 \mathrm{~mm}$, which, together with their considerably young age, ensures a better quality of meat. The model, then, explores biological efficiency (live weight gain relative to energy consumption) and combines the effects of genetic and environmental factor manipulation in tissue transformation during accelerated growth (Rubiano et al., 2009).

Besides these aspects related to efficiency, Lovett et al. (2003) also alert for the problem of $\mathrm{CH}_{4}$ emissions derived from enteric fermentation. The authors comment about many potential strategies as a means by which $\mathrm{CH}_{4}$ production (resulting from enteric fermentation) could be reduced and one of them is the alteration of ruminal fermentation patterns through dietary manipulation; primarily the substitution of structural by non-structural carbohydrates. The authors concluded that the feeding of low $\mathrm{F} / \mathrm{C}$ ratio diets to finishing beef animals is an effective means to reduce $\mathrm{CH}_{4}$ output per unit of product while simultaneously improving animal productivity. Conclusion also obtained by Aguerre et al. (2011) working with dairy cows and measuring the $\mathrm{CH}_{4}$ emissions and for Mathot et al. (2012) who evaluated the effect of cattle diet and manure storage conditions on carbon dioxide, methane and nitrous oxide emissions from tie-stall barns and stored solid manure. These important changes in the calf raising model, based on the use of young bulls, are expected to affect directly the quantitative and qualitative characteristics of manure. Thus, manure produced from young bulls needs to be evaluated for its pollution potential. Also, it is important to determine the agronomic potential of manure produced according to the current calf raising model, by using anaerobic digestion systems to estimate the production of clean energy in the form of biogas, and the quality of the final biofertilizer.

Here, we evaluated biogas production from the manure of young bulls fed on diets differing in the ratio of concentrate (C) to forage $(F)$. Biogas production during anaerobic biodigestion was evaluated in reactors operated in a semi-continuous system, at three different temperature levels, with or without the use of an inoculum. Also, we measured the levels of macronutrients in the final biofertilizer produced by anaerobic digestion, to evaluate the agronomic value of the manure generated under different conditions.

\section{Materials and methods}

\subsection{Animals}

The manure residues used in this work were collected from Brangus breed cattle kept in the feedlot area of the Lageado Farm (Faculty of Veterinary Medicine and Animal Husbandry, São Paulo State University - FMVZ/UNESP - Botucatu, SP, Brazil). In a covered confinement area, each $5 \times 5$-m masonry bay housed 6 animals, with a suspended and perforated floor that facilitated manure collection from the lower part of the bay. Manure collection was performed 1 week after the initiation of feeding with experimental diets.

\subsection{Biodigesters and experimental design}

Anaerobic digestion of cattle manure was performed in PVC bench digesters with 10-L capacity and fed in a semi-continuous system, as described in Hardoim (1999). Anaerobic digestion experiments followed a randomized factorial design comprising 12 treatments ( 2 diets $\times 3$ temperature levels $\times$ presence or absence of an inoculum in the digestion mixture), with two repli- cates each, totaling 24 digesters. The duration of the assay was 58 days, but the period in which the data was collected was 31 days. The first 9 days and the last 17 days were discarded.

The manure used was produced by young bulls that had received one of the following two diets, which differed in the ratio of concentrate (C) to forage ( $\mathrm{F})$ : $65 \% \mathrm{C}+35 \% \mathrm{~F}$ ('LowC' diet) and $80 \%$ $\mathrm{C}+20 \% \mathrm{~F}$ ('HighC' diet). This proportion is in the dry matter basis. The diets were formulated using corn silage (whole plant and wet grain), pre-dried alfalfa and mineral mix. The bromatological characteristics of the two diets given to the animals are shown in Table 1.

The composition of the manure produced by cattle fed on each diet and used to compose the daily loading is shown in Table 2.

Anaerobic digestion was performed at 25,35 , or $40^{\circ} \mathrm{C}$. For temperature control, anaerobic digesters were placed in 500 -L fiber cement boxes (in batches of 8 digesters/box). Boxes were thermally insulated through a 3-cm polystyrene (Styrofoam) wrap containing $270 \mathrm{~L}$ of water, which was heated to the desired temperature thorough a heating system with electrical resistances of 1000,3000 , and $5000 \mathrm{~W}$ (for temperatures of 25,35 , and $40{ }^{\circ} \mathrm{C}$, respectively) and a thermostat $(20 \mathrm{~A})$. Homogenization was ensured by the use of a 150-W water pump in each box, which triggered water movement whenever the thermostat activated the heating system (Souza et al., 2005).

To start the process, within each batch of eight digesters kept at a set temperature condition $\left(25,35\right.$, or $\left.40^{\circ} \mathrm{C}\right)$, half $(4 / 8)$ were filled with substrate containing manure from animals fed on the LowC diet while the other half contained manure from animals given the HighC diet. Substrates (LowC and HighC) were obtained from bench digesters $(10 \mathrm{~L})$ operated in batch system for 172 days. Also, 2 digesters in each group of 4 contained an inoculum. The inoculum used was the effluent of real scale digester $\left(5.5 \mathrm{~m}^{3}\right)$ operated with beef cattle manure and water ( $8 \% \mathrm{TS}$ ) with 30 days of hydraulic retention time (HRT) on semi-continuous system. The real scale digester is located at São Paulo State University - Department of

Table 1

Bromatological composition of the diets given to animals during anaerobic digestion assay.

\begin{tabular}{cccccccccc}
\hline \multirow{2}{*}{ Diet } & DM & CP & CF & EE & NFE & TDN & NDF & ADF & MM \\
\cline { 2 - 9 } & \%DM & & & & & & & & \\
\hline LowC & 48.1 & 19.6 & 19.5 & 5.28 & 50.1 & 68.9 & 51.2 & 21.0 & 5.49 \\
HighC & 55.6 & 15.8 & 10.7 & 4.44 & 63.9 & 74.2 & 40.3 & 14.2 & 5.08 \\
\hline
\end{tabular}

DM: dry matter; CP: crude protein; CF: crude fiber; EE: ether extract; NFE: nitrogen free extract; TDN: total digestible nutrients; NDF: neutral detergent fiber; ADF: acid detergent fiber; MM: mineral matter.

Table 2

Characterization of manure produced by cattle fed on diets containing $65 \%$ concentrate $+35 \%$ forage ('LowC' diet) and $80 \%$ concentrate $+20 \%$ forage ('HighC' diet).

\begin{tabular}{lrr}
\hline Components & \multicolumn{1}{c}{ LowC diet } & \multicolumn{1}{c}{ HighC diet } \\
\hline TS (\%) & $20.0 \pm 0.21$ & $24.2 \pm 2.7$ \\
VS (\%) & $82.7 \pm 1.12$ & $87.0 \pm 0.10$ \\
N (\%) & $2.15 \pm 0.05$ & $2.20 \pm 0.02$ \\
P (\%) & $0.27 \pm 0.00$ & $0.26 \pm 0.02$ \\
K (\%) & $1.71 \pm 0.01$ & $2.44 \pm 0.04$ \\
CF (\%) & $22.81 \pm 1.96$ & $17.7 \pm 1.67$ \\
NDF (\%) & $53.07 \pm 3.04$ & $47.6 \pm 1.60$ \\
ADF (\%) & $34.2 \pm 3.39$ & $30.6 \pm 3.98$ \\
NFE (\%) & $47.83 \pm 3.04$ & $50.30 \pm 2.67$ \\
MM (\%) & $14.24 \pm 1.26$ & $16.40 \pm 1.48$ \\
CP (\%) & $14.16 \pm 1.10$ & $13.47 \pm 0.16$ \\
EE (\%) & $1.96 \pm 0.71$ & $2.16 \pm 0.44$ \\
TDN (\%) & $62.60 \pm 1.26$ & $64.32 \pm 1.80$ \\
\hline
\end{tabular}

TS: total solids; VS: volatile solids; N: nitrogen. 
Rural Engineering - Jaboticabal - São Paulo - Brazil. The average temperature of the digester substrate and later used as the inoculum, was around $30^{\circ} \mathrm{C}$. The substrate to inoculum ratio was $1: 1$, or $4 \mathrm{~L}$ of substrate to $4 \mathrm{~L}$ of inoculum, so the initial load in all digesters was $8 \mathrm{~L}$. Experimental groups for each temperature condition were as follows: 'LowC + in' (LowC diet, with inoculum), 'LowC-in' (LowC diet, without inoculum), 'HighC + in' (HighC diet, with inoculum), 'HighC-in' (HighC diet, without inoculum).

The chemical composition of the substrates of different diets and of the inoculum are shown in Table 3.

\subsection{Quantification of the biogas production potential}

Each anaerobic digester had an independent gasometer, with a capacity of $15 \mathrm{~L}$ of biogas, to store and allow the quantification of the biogas produced, through a graduated scale attached to the outside wall. All gasometers were placed in a fiber cement box of 1000 -L capacity, containing approximately $750 \mathrm{~L}$ of water and a 5 -mm layer of hydraulic fluid, which maintained biogas pressure and avoided absorption of the $\mathrm{CO}_{2}$ produced (Miranda, 2009). Biogas production was determined by measuring the vertical displacement of the gasometers and multiplying it by the area of the gasometer's inner cross section (i.e., $0.030887 \mathrm{~m}^{2}$ ), and measurements were corrected for conditions of $1 \mathrm{~atm}$ and $20^{\circ} \mathrm{C}$, as described by Caetano (1985). Gasometers were zeroed after each reading which was performed whenever the mark on the ruler recorded was at least $50 \%$ of the total height.

The daily load in the anaerobic digesters was composed of $60.8 \mathrm{~g}$ of manure and $139.2 \mathrm{~g}$ of water, resulting in $0.20 \mathrm{~L}$ of substrate per day, and a hydraulic retention time (HRT) of 40 days. The percentage of total solids (TS) in the influent ranged from $6 \%$ to $8 \%$. The levels of TS and volatile solids (VS) in the influents and effluents of bench anaerobic digesters were determined as described by APHA/AWWA/WEF (2005).

Biogas production values were calculated dividing the daily average production values by the amount of manure in natura added, and also the amount of TS and VS added to digesters during anaerobic digestion. Biogas production values were expressed as $\mathrm{m}^{3}$ of biogas per $\mathrm{kg}$ of TS added, per $\mathrm{kg}$ of VS added, or per $\mathrm{kg}$ of manure added.

\subsection{Macronutrient quantification}

For macronutrient determination, manure and substrate samples were dried at $65^{\circ} \mathrm{C}$ in a forced air oven (up to a constant mass), ground in a cutting mill, and digested completely in a Digesdahl Hach digester, using a mixture of sulfuric acid $\left(\mathrm{H}_{2} \mathrm{SO}_{4}\right)$ and hydrogen peroxide $\left(\mathrm{H}_{2} \mathrm{O}_{2}\right)$ at $50 \%$. The levels of nitrogen, phosphorus,

Table 3

The chemical composition of substrates of 'LowC' diet and 'HighC diet' and of the inoculum used in biodigester loading.

\begin{tabular}{llll}
\hline Nutrient & $\begin{array}{l}\text { Substrate LowC } \\
\text { diet }\end{array}$ & $\begin{array}{l}\text { Substrate HighC } \\
\text { diet }\end{array}$ & Inoculum \\
\hline $\mathrm{pH}$ & 7.36 & 7.37 & 6.67 \\
Nitrogen $(\mathrm{g} / 100 \mathrm{~g})$ & 2.55 & 3.06 & 2.28 \\
Phosphorus $(\mathrm{g} / 100 \mathrm{~g})$ & 1.38 & 1.44 & 1.00 \\
Potassium $(\mathrm{g} / 100 \mathrm{~g})$ & 6.71 & 4.97 & 1.56 \\
Calcium $(\mathrm{g} / 100 \mathrm{~g})$ & 0.88 & 0.71 & 1.77 \\
Magnesium $(\mathrm{g} / 100 \mathrm{~g})$ & 2.76 & 3.06 & 0.97 \\
Sodium $(\mathrm{g} / 100 \mathrm{~g})$ & 1.72 & 2.55 & 9.20 \\
Iron $(\mathrm{mg} / 100 \mathrm{~g})$ & 456 & 546 & 389 \\
Copper $(\mathrm{mg} / 100 \mathrm{~g})$ & 13.0 & 24.2 & 6.74 \\
Manganese $(\mathrm{mg} / 100 \mathrm{~g})$ & 27.0 & 21.0 & 26.1 \\
Zinc $(\mathrm{mg} / 100 \mathrm{~g})$ & 76.2 & 63.4 & 28.3 \\
Cobalt $(\mathrm{mg} / 100 \mathrm{~g})$ & 11.2 & 11.9 & 9.99 \\
\hline
\end{tabular}

potassium, calcium, magnesium, sodium, iron, copper, manganese, zinc and cobalt in digestion extracts were determined according to Bataglia et al. (1983). Total nitrogen was determined through a micro-Kjeldahl distiller, using the methodology described by Silva and Queiroz (2002). Phosphorus levels were determined by a colorimetric method using a HACH DR-2000 spectrophotometer ( $\mathrm{HACH})$, using standards prepared according to the methodology described by Malavolta et al. (1989). Potassium, calcium, magnesium, sodium, copper, manganese, zinc and cobalt concentrations were determined in a GBC 932 AA atomic absorption spectrophotometer (GBC Scientific Equipment).

\subsection{Bromatological analysis}

The bromatological analysis of the diets (LowC and HighC) were held at the Bromatological Laboratory of the Animal Production Department of FMVZ/Unesp. The dry matter (DM), mineral matter $(\mathrm{MM})$, crude protein $(\mathrm{CP})$ and ether extract (EE) were determined according AOAC (1984) protocols. Crude Fiber (CF), Neutral detergent fiber (NDF) and acid detergent fiber (ADF) were verified according Van Soest et al. (1991). Nitrogen free extract (NFE) and Total digestible nutrients (TDN) were calculated by the formula suggested by Weiss (NRC, 2001):

$$
\begin{aligned}
\mathrm{NFE}= & 100-(\mathrm{CP}+\mathrm{EE}+\mathrm{MM}+\mathrm{CF}) \\
\mathrm{TDN}= & 40.2625+(0.1969 * \% \mathrm{CP})+(0.4228 * \% \mathrm{NFE}) \\
& +(1.1903 * \% \mathrm{EE})-(0.1379 * \% \mathrm{CF})
\end{aligned}
$$

The bromatological characterization of the manures produced by animals fed with diets HighC and LowC were held the Bromatological Laboratory from FCA/Unesp, according to methodology described by Silva and Queiroz (2002). The formulas used to calculate NFE and TDN are the same cited above.

\subsection{Statistical analysis}

Results for daily average biogas production, biogas production per $\mathrm{kg}$ of TS, VS and manure added, VS reduction, and macronutrient concentration in the final biofertilizer were subjected to ANOVA followed by Tukey's test (with $p \leqslant 0.05$ considered statistically significant), adopting a $2 \times 2 \times 3$ factorial design (2 diets, with and without inoculum, and 3 temperature levels), considering two replicas per treatment and 31 days of data collection for the measurements of biogas production and VS reduction.

\section{Results and discussion}

\subsection{Biogas production}

Given the changes in the calf raising model in Brazil, with increasing use of younger bulls fed on diets richer in concentrate, we sought to test the potential of young bulls' manure for biogas and biofertilizer production, after anaerobic biodigestion. The three factors, diet, temperature and inoculum were statistically compared and the results revealed a triple interaction among them (Table 4). The greatest biogas production per $\mathrm{kg}$ of manure, TS and VS added was observed when the manure from young bulls fed on the HighC diet ( $80 \%$ concentrate $+20 \%$ forage) was subjected to anaerobic digestion with the use of an inoculum, in reactors operated at temperatures of 35 or $40{ }^{\circ} \mathrm{C}$ (Table 5).

Our results may be explained by the fact that the ideal anaerobic digestion conditions observed here combine factors known to positively influence the biogas production. Mesophilic temperatures $\left(35-37^{\circ} \mathrm{C}\right)$ are commonly considered optimal for maintaining the stability of bacterial activity and the production of biogas from animal manure (Sakar et al., 2009). Also, the use of digested 
Table 4

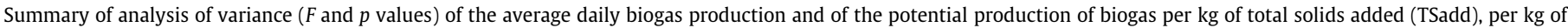
volatile solids added (VSadd) and per kg of manure (manure), depending on the different diets $(D)$, substrate temperatures $(T)$ and usage or not of an inoculum $(I)$.

\begin{tabular}{|c|c|c|c|c|c|c|c|c|}
\hline \multirow[t]{2}{*}{ Source of variation } & \multicolumn{2}{|c|}{ Daily average } & \multicolumn{2}{|l|}{$\mathrm{TS}_{\text {adic }}$} & \multicolumn{2}{|l|}{$\mathrm{VS}_{\text {adic }}$} & \multicolumn{2}{|l|}{ Manure } \\
\hline & $F$ & $p$ & $F$ & $p$ & $F$ & $p$ & $F$ & $p$ \\
\hline Diet $(D)$ & $497.98^{*}$ & 0.000000 & $400.33^{*}$ & 0.000000 & $457.66^{*}$ & 0.000000 & $497.98^{*}$ & 0.000000 \\
\hline Inoculum (I) & $81.68^{*}$ & 0.000000 & $84.08^{*}$ & 0.000000 & $82.64^{*}$ & 0.000000 & $81.68^{*}$ & 0.000000 \\
\hline Temperature $(T)$ & $163.51^{*}$ & 0.000000 & $164.31^{*}$ & 0.000000 & $163.84^{*}$ & 0.000000 & $163.51^{*}$ & 0.000000 \\
\hline$D \times I$ & $14.36^{*}$ & 0.000163 & $15.87^{*}$ & 0.000075 & $14.96^{*}$ & 0.000120 & $14.36^{*}$ & 0.000163 \\
\hline$D \times T$ & $8.97^{*}$ & 0.000142 & $7.72^{*}$ & 0.000482 & $8.46^{*}$ & 0.000234 & $8.97^{*}$ & 0.000142 \\
\hline$I \times T$ & $4.67^{*}$ & 0.009614 & $4.94^{*}$ & 0.007409 & $4.78^{*}$ & 0.008667 & $4.67^{*}$ & 0.009614 \\
\hline$D \times I \times T$ & $6.88^{*}$ & 0.001096 & $7.17^{*}$ & 0.000822 & $7.00^{*}$ & 0.000977 & $6.88^{*}$ & 0.001096 \\
\hline
\end{tabular}

* Significant at $5 \%$.

Table 5

Average biogas production and average daily production, corrected to $20{ }^{\circ} \mathrm{C}$ and $1 \mathrm{~atm}$, per $\mathrm{kg}$ of total and volatile solids and of manure solids

\begin{tabular}{|c|c|c|c|c|c|}
\hline Potential of production ( $\mathrm{m}^{3}$ biogas) & Temp $\left({ }^{\circ} \mathrm{C}\right)$ & LowC diet + in & LowC diet - in & HighC diet + in & HighC diet - in \\
\hline Daily average $\left(\mathrm{m}^{3}\right)$ & $\begin{array}{l}40 \\
35 \\
25\end{array}$ & $\begin{array}{l}0.0064 \mathrm{Abx} \\
0.0055 \mathrm{Abx} \\
0.0044 \mathrm{Bbx}\end{array}$ & $\begin{array}{l}0.0044 \text { Aby } \\
0.0049 \text { Aby } \\
0.0036 \text { Bby }\end{array}$ & $\begin{array}{l}0.0079 \text { Aax } \\
0.0077 \text { Aax } \\
0.0056 \text { Bax }\end{array}$ & $\begin{array}{l}0.0075 \text { Aay } \\
0.0071 \text { Aay } \\
0.0053 \text { Bay }\end{array}$ \\
\hline kg TS added & $\begin{array}{l}40 \\
35 \\
25\end{array}$ & $\begin{array}{l}0.4525 \mathrm{Abx} \\
0.3917 \mathrm{Abx} \\
0.3135 \mathrm{Bbx}\end{array}$ & $\begin{array}{l}0.3134 \text { Aby } \\
0.3469 \text { Aby } \\
0.2559 \text { Bby }\end{array}$ & $\begin{array}{l}0.5383 \text { Aax } \\
0.5282 \text { Aax } \\
0.3854 \text { Bax }\end{array}$ & $\begin{array}{l}0.5109 \text { Aay } \\
0.4847 \text { Aay } \\
0.3611 \text { Bay }\end{array}$ \\
\hline kg VS added & $\begin{array}{l}40 \\
35 \\
25\end{array}$ & $\begin{array}{l}0.5201 \mathrm{Abx} \\
0.4503 \mathrm{Abx} \\
0.3603 \mathrm{Bbx}\end{array}$ & $\begin{array}{l}0.3602 \text { Aby } \\
0.3988 \text { Aby } \\
0.2942 \text { Bby }\end{array}$ & $\begin{array}{l}0.6326 \text { Aax } \\
0.6207 \text { Aax } \\
0.4529 \text { Bax }\end{array}$ & $\begin{array}{l}0.6004 \text { Aay } \\
0.5696 \text { Aay } \\
0.4243 \text { Bay }\end{array}$ \\
\hline $\mathrm{kg}$ of manure & $\begin{array}{l}40 \\
35 \\
25\end{array}$ & $\begin{array}{l}0.1049 \mathrm{Abx} \\
0.0908 \mathrm{Abx} \\
0.0727 \mathrm{Bbx}\end{array}$ & $\begin{array}{l}0.0727 \text { Aby } \\
0.0804 \text { Aby } \\
0.0593 \text { Bby }\end{array}$ & $\begin{array}{l}0.1295 \text { Aax } \\
0.1271 \text { Aax } \\
0.0927 \text { Bax }\end{array}$ & $\begin{array}{l}0.1229 \text { Aay } \\
0.1166 \text { Aay } \\
0.0869 \text { Bay }\end{array}$ \\
\hline
\end{tabular}

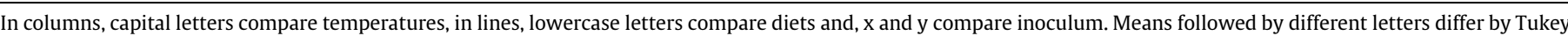
test $(p<0.05)$.

materials as a source of inoculum increases anaerobic digestion performance ( $\mathrm{Gu}$ et al., 2014; Hidalgo and Martín-Marroquín, 2014). Lastly, Orrico et al. (2010, 2012) reported lower biogas and methane production from the manure of young bulls fed on diets with a higher proportion of forage relative to concentrate.

Other studies also reported that feeding beef cattle with highly concentrated diets $(60 \% \mathrm{C}+40 \% \mathrm{~F})$ results in the production of manures with higher biogas production (Orrico et al., 2010, 2012; Costa et al., 2013). Importantly, these results were obtained by using a range of HRTs in batch systems (Orrico et al., 2010) and genotypes (Orrico et al., 2012). Notably, the values for biogas production that we obtained (Table 4) were much higher than those reported by others (on average $0.20 \mathrm{~m}^{3}$ per $\mathrm{kg}$ of VS added). This difference might be explained (at least in part) by the operation of reactors in a semi-continuous system, compared with the batch system used in other studies (Orrico et al., 2010, 2012; Costa et al., 2013). As the calculation of the biogas production consider the division of total volume of biogas (in batch assays) or the daily volume of biogas (in semi-continuous systems) by the amount of TS and VS added, it could result in greater biogas production for semi-continuous system because of the higher daily volumetric yield.

The higher production of biogas from HighC diets can also be explained by the quality of carbon present in the manure. As the HighC diet presents more percentage of concentrate (80\%) than LowC diet (65\%), the manure produced by animals fed with LowC diet presented more content of fiber (CF, NDF and ADF) (see Table 2). And according to other studies, when the animals are fed with less amount of fiber, the $\mathrm{CH}_{4}$ emission from enteric fermentation decreases (Lovett et al., 2003; Aguerre et al., 2011; Mathot et al., 2012). So, we can infer that the manure from the animals fed with HighC diet has more readily $\mathrm{C}$ available for anaerobic digestion and it implies in more biogas production. The content of NFE (nitrogen free extract) indirectly reflects the content of non-structural carbohydrates and more digestible as sugars, starch and pectin. The content of NFE is major in the manure from HighC diet than in LowC diet (Table 2).

In the batch feeding trial most comparable to our study (Costa et al., 2013), a double interaction was reported between dietary factors and inoculum, as opposed to the triple interaction observed here. Anaerobic digestion without inoculum of the manure from animals fed on HighC diet yielded the highest potential for biogas production per $\mathrm{kg}$ of added TS $\left(0.2123 \mathrm{~m}^{3}\right)$, and per $\mathrm{kg}$ of added VS $\left(0.2511 \mathrm{~m}^{3}\right.$; Costa et al., 2013). These results can be explained by the type of inoculum used. The main function of the biofertilizer (stabilized material), when used as an inoculum, is to provide biomass to start anaerobic digestion faster, accelerating biogas production, as observed in this trial; however, the inoculum occupies some of the usable volume of the fermentation chamber. Therefore, in the final results, biogas production values per reactor may be lower when compared to those obtained using reactors containing a larger volume of substrate (manure + water) to be digested. Just like in the test with reactors operating in a semicontinuous system, only the initial charge used an inoculum, which was gradually replaced by the substrate with only manure and water.

The values for biogas production from the manure of young bulls obtained in treatment $\mathrm{HighC}+$ in at $40{ }^{\circ} \mathrm{C}(0.5383$ and $0.6326 \mathrm{~m}^{3}$ of biogas per kg of TS and VS added, respectively) were comparable to those reported for pig slurry (Orrico et al., 2009, 2011; Miranda et al., 2012), and considerably higher than those reported for the anaerobic digestion of manure from confined beef 
Table 6

Summary of variance analysis ( $F$ and $p$ values) of the reduction of VS depending on the different diets $(D)$, substrate temperatures $(T)$ and use or not of inoculum $(I)$.

\begin{tabular}{lll}
\hline Source of variation & \multicolumn{2}{l}{ VS reduction } \\
\cline { 2 - 3 } & $F$ & $p$ \\
\hline Diet $(D)$ & $14.7^{*}$ & 0.000134 \\
Inoculum $(I)$ & $15.7^{*}$ & 0.000000 \\
Temperature $(T)$ & $31.9^{*}$ & 0.000000 \\
$D \times I$ & $1.1^{\mathrm{ns}}$ & 0.325581 \\
$D \times T$ & $0.6^{\mathrm{ns}}$ & 0.437161 \\
$I \times T$ & $1.5^{\mathrm{ns}}$ & 0.213445 \\
$\mathrm{D} \times \mathrm{I} \times \mathrm{T}$ & $0.1^{\mathrm{ns}}$ & 0.921339 \\
\hline
\end{tabular}

ns Non-significant.

Significant at $5 \%$

Table 7

Mean values of reduction in VS as a function of different factors.

\begin{tabular}{ll}
\hline Temperature & VS reduction \\
\hline 40 & $82.16 \mathrm{~A}$ \\
35 & $81.18 \mathrm{~A}$ \\
25 & $79.50 \mathrm{~B}$ \\
Diets & VS reduction \\
\hline LowC & $80.19 \mathrm{~B}$ \\
HighC & $81.70 \mathrm{~A}$ \\
Inoculum & VS reduction \\
\hline -in & $79.84 \mathrm{~B}$ \\
+in & $82.05 \mathrm{~A}$ \\
\hline
\end{tabular}

Different capital letters within each factor differ statistically at $5 \%$ probability.

cattle or dairy cows (Amon et al., 2007; Comino et al., 2009; Orrico et al., 2011).

Concerning the content of methane in the biogas, we can cite the results obtained by Orrico et al. $(2010,2012)$ which conducted experiments under similar conditions in Brazil. The authors concluded that the manure from animals that received more concentrated diets (60\% of concentrate $+40 \%$ of forage) produced $23 \%$ and $26.3 \%$ more methane than those fed with $40 \%$ of concentrate $+60 \%$ of forage, respectively for both assays. In both experiments the author observed a relation between the methane production and VS degradation. In our research, we did not measure the methane content but we also observed that the content of VS is superior at HighC diet (87.04\%) than at LowC diet $(82.66 \%)$ and its degradation is higher on HighC diet than LowC diet $(p<0.001)$.
Table 9

Concentration of macronutrients $(\mathrm{N}, \mathrm{P}$, and $\mathrm{K})$ in biofertilizers produced by anaerobic digestion of the manure of young bulls fed on different diets.

\begin{tabular}{lll}
\hline & \multicolumn{2}{c}{ Diets } \\
\cline { 2 - 3 } Macronutrient (\%) & LowC & HighC \\
\hline $\mathrm{N}$ & $2.43 \mathrm{~B}$ & $2.97 \mathrm{~A}$ \\
$\mathrm{P}$ & $1.23 \mathrm{~B}$ & $1.41 \mathrm{~A}$ \\
$\mathrm{~K}$ & $2.27 \mathrm{~B}$ & $3.25 \mathrm{~A}$ \\
\hline
\end{tabular}

Different capital letters within each factor differ statistically at 5\% probability.

\subsection{VS reduction}

The reduction in VS during the study period (Table 6) was also subjected to ANOVA, which did not reveal statistically significant interactions among the factors.

As there was no interaction among the factors, the results were separated and are shown in Table 7.

It should be noted that quantifying the reduction in solids in reactors operated in semi-continuous systems is technically challenging, particularly when the daily load has a high content of solids (in this case, between $6 \%$ and $8 \%$ ). Samples tend to become segregated and it is not possible to homogenize the substrate before removal, which makes sampling relatively inaccurate especially regarding the settling of solids in the digester bottom, which in turn, may overstate the reduction values. For this reason, probably we did not find triple interaction among the factors as we observed for biogas production. Even without interactions, however, the largest VS reductions were observed at $40^{\circ} \mathrm{C}$ and $35^{\circ} \mathrm{C}$, with manure from animals fed on a HighC+ in (Table 6). The reduction in VS implies greater production of biogas, despite the statistical difference between LowC and HighC diets being only $2 \%$ in VS reduction, probably because of the sampling difficulty; thus, the values are consistent with those presented in Table 5.

\subsection{Agronomic value of biofertilizer}

The concentration of macronutrients in the biofertilizer produced by each treatment during reactor storage was determined, and the results were submitted to variance analysis. The summary of this analysis is presented in Table 8 .

The statistical analysis of the results by ANOVA revealed that only the diet factor influenced the concentration of macronutrients in the final biofertilizer. Specifically, the animals given the HighC diet produced manures that, after anaerobic digestion, had higher concentration of the macronutrients $\mathrm{N}, \mathrm{P}$, and $\mathrm{K}$ (Table 9).

Orrico et al. (2012) observed differences $(p<0.01)$ in manure composition upon changes in the ratio of forage to concentrate in diets. These authors found higher values of nitrogen $\left(\mathrm{g} \mathrm{kg}^{-1} \mathrm{TS}\right)$ in the manures of animals fed on diets higher in concentrate than in forage.

Table 8

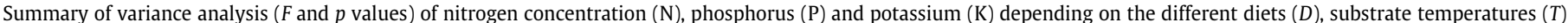
and use or not inoculum $(I)$.

\begin{tabular}{|c|c|c|c|c|c|c|}
\hline \multirow[t]{2}{*}{ Source of variation } & \multicolumn{2}{|l|}{$\mathrm{N}$} & \multicolumn{2}{|l|}{$\mathrm{P}$} & \multicolumn{2}{|l|}{$\mathrm{K}$} \\
\hline & $F$ & $p$ & $F$ & $p$ & $F$ & $p$ \\
\hline Diet $(D)$ & $26.280^{*}$ & 0.000251 & $11.955^{*}$ & 0.004738 & $8.3792^{*}$ & 0.013459 \\
\hline Inoculum $(I)$ & $3.097^{\mathrm{ns}}$ & 0.082330 & $1.542^{\mathrm{ns}}$ & 0.253457 & $2.9102^{\mathrm{ns}}$ & 0.093236 \\
\hline Temperature $(T)$ & $1.116^{\mathrm{ns}}$ & 0.311548 & $0.060^{\mathrm{ns}}$ & 0.810622 & $1.8873^{\mathrm{ns}}$ & 0.194629 \\
\hline$D \times I$ & $0.590^{\mathrm{ns}}$ & 0.569607 & $0.213^{\text {ns }}$ & 0.810797 & $1.3963^{\mathrm{ns}}$ & 0.284992 \\
\hline$D \times T$ & $0.026^{\mathrm{ns}}$ & 0.873885 & $2.094^{\mathrm{ns}}$ & 0.173498 & $3.6690^{\mathrm{ns}}$ & 0.079565 \\
\hline$I \times T$ & $0.392^{\mathrm{ns}}$ & 0.684300 & $0.218^{\mathrm{ns}}$ & 0.807431 & $0.2026^{\mathrm{ns}}$ & 0.819376 \\
\hline$D \times I \times T$ & $1.309^{\mathrm{ns}}$ & 0.306137 & $0.377^{\mathrm{ns}}$ & 0.693452 & $0.2577^{\mathrm{ns}}$ & 0.776966 \\
\hline
\end{tabular}

ns Non significant.

Significant at $5 \%$ 
Table 10

Amount of macronutrient produced per animal considering the LowC and HighC diets.

\begin{tabular}{|c|c|c|c|c|c|c|c|}
\hline Diet & $\mathrm{N}(\mathrm{kg})$ & $\begin{array}{l}\text { Ammonium } \\
\text { sulfate }(\mathrm{kg})\end{array}$ & $\mathrm{P}(\mathrm{kg})$ & $\begin{array}{l}\text { Simple superphosphate } \\
(\mathrm{kg})\end{array}$ & $\mathrm{K}(\mathrm{kg})$ & Potassium chloride $(\mathrm{kg})$ & $\begin{array}{l}\text { Hectares of corn } \\
\left(120 \mathrm{~kg} \mathrm{~N} \mathrm{ha}^{-1}\right)\end{array}$ \\
\hline LowC & 6.5 & 32.5 & 4 & 51.0 & 6.1 & 12.2 & 0.054 \\
\hline HighC & 8 & 40 & 3.3 & 42.0 & 9 & 18.0 & 0.070 \\
\hline
\end{tabular}

$\mathrm{N}$ to Ammonium nitrate $=(\% \mathrm{~N} * 20) / 100$.

$\mathrm{P}$ to simple superphosphate $(\mathrm{SS})=((\% \mathrm{P} * 2.29) * 100) / 18$.

$\mathrm{K}$ to potassium chloride $(\mathrm{KCl})=((\% \mathrm{~K} * 1.20548) * 100) / 60$.

As the main characteristic of the HighC diet is the increase in the concentrate related to forage, we can observe that the content of $\mathrm{N}, \mathrm{P}$ and $\mathrm{K}$ in the manure of both diets did not present expressive difference (Table 2). Mathot et al. (2012) also did not find significantly influence of the diet $(p>0.05)$, in the proportion and total amount of $\mathrm{N}$ lost from a tie-stall system (barns and solid manure storage facilities) for beef heifers. However, as the concentrate is rich in non-structural carbohydrate, i.e., readily available carbon, the anaerobic digestion promotes the concentration of macronutrients by the loss of carbon, mainly in the form of $\mathrm{CH}_{4}$.

Considering an average residue coefficient (RC) of $1.99 \mathrm{~kg}$ of waste (dry matter) per $\mathrm{kg}$ of meat produced in the confinement system for young bulls, and an average weight gain of $1.7 \mathrm{~kg} \mathrm{day}^{-1}$ (Costa, 2005), each animal produces $382.3 \mathrm{~kg}$ of manure (dry matter) in 113 days, on average, during the fattening period (i.e., excluding a period of adaptation to the combined diets). Considering a mixture of $6 \%$ of TS, this amount of waste is sufficient to produce $6383 \mathrm{~L}$ of biofertilizer (under the conditions tested here), with a TS content of $4.2 \%$ (data not shown) resulting $268 \mathrm{~kg}$ of dry matter. With this information we present Table 10 containing the macronutrient mass balance for both diets.

Considering the data from Table 10 it is possible to calculate the number of young bulls to produce 1 hectare of corn (based on $120 \mathrm{~kg} \mathrm{~N} \mathrm{ha}^{-1}$ ), 18.5 for LowC diet and 15 for High C diet. It is also possible to calculate the energy produced per young bull fed with each diet. Considering the biogas production average at 35 and $40{ }^{\circ} \mathrm{C}$ and the use of an inoculum (Table 5) and the index of $1.8 \mathrm{~kW} \mathrm{~h}$ per $\mathrm{m}^{3}$ of biogas produced, each young bull produces

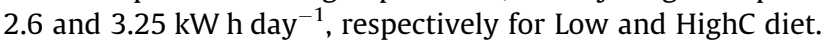

Studies regarding the LCA (Life Cycle Assessments) such as the presented by de Vries et al. (2015) concluded that lower Global Warming Potential - GWP (on average 28\% lower), energy use (13\% lower) and land use ( $41 \%$ lower) per unit of beef were found for concentrate-based compared with roughage-based systems.

This kind of exercise permits to discuss about the advantages and disadvantages of this animal production system. Many authors alert to the problems with animal welfare with the use of high concentrate diets, mainly the risk of ruminal acidosis (Bulle et al., 2002; Torquato et al., 2012; González et al., 2012). However, other disadvantages such as high production cost (Ferreira et al., 2009; Pereira et al., 2009; Ogino et al., 2015) and the environmental impacts caused by the manure high organic load (Ogino et al., 2015; de Vries et al., 2015) could be, if not solved, at least alleviated, by considering the agronomic and energetic recovery of the manure generated in the system. Besides this, the waste biomass for energy production is always an interesting source of renewable energy and can make the difference in water crisis time. In fact, the choice for young bulls confinement systems will depends on the economic and energetic scenario. But always the manure recovery will contribute for the sustainability of the activity.

\section{Conclusions}

When subjected to anaerobic digestion in a semi-continuous system, the manure produced by young bulls has higher biogas production when animals receive diets richer in concentrate than in forage ( $80 \%$ concentrate and $20 \%$ forage), and when anaerobic digestion is performed with an inoculum, at temperatures of $35^{\circ} \mathrm{C}$ or $40^{\circ} \mathrm{C}$. Also, the biofertilizer generated from the anaerobic digestion of manure from animals fed on HighC diets has higher macronutrient content, and thus a greater agronomic value.

\section{Funding}

We thank the Coordination for the Improvement of Higher Education Personnel (CAPES) for the assignment of the first author doctoraĺs scholarship. This research received no specific grant from any funding agency in the public, commercial, or not-for-profit sectors.

\section{Acknowledgements}

Special thanks to Western Parana State University and Sao Paulo State University - Rural Engineering (FCA and FCAV/UNESP) and Animal Production Department (FCA/UNESP).

\section{References}

Aguerre, M.J., Wattiaux, M.A., Powell, J.M., Broderick, G.A., Arndt, C., 2011. Effect of forage-to-concentrate ratio in dairy cow diets on emission of methane, carbon dioxide, and ammonia, lactation performance, and manure excretion. J. Dairy Sci. 94, 3081-3093. http://dx.doi.org/10.3168/jds.2010-4011.

American Public Health Association; American Water Works Association; Water Environment Federation - APHA/AWWA/WEF, 2005. Standard Methods for Examination of Water and Manure Water, 21st ed. American Water Works Association, Washington, D.C., 1368p.

Amon, T., Amon, B., Kryvoruchko, V., Zollitsch, W., Mayer, K., Gruber, L., 2007. Biogas production from maize and dairy cattle manure - influence of biomass composition on the methane yield. Agric. Ecosyst. Environ. Amsterdam 118 $173-182$.

AOAC, 1984. Official Methods of Analysis of the Association. Association Official Chemists, Washington.

Bataglia, O.C., Furlani, A.M.C., Teixeira, J.P.F., Furlani, P.R., Gallo, J.R., 1983. Métodos de análises químicas de plantas. Instituto Agronômico, Campinas, 48p (Boletim Técnico 78).

Bulle, M.L.de.M., Ribeiro, F.G., Leme, P.R., Titto, E.A.L., Lanna, D.P.D., 2002 Desempenho de tourinhos cruzados em dietas de alto teor de concentrado com bagaço de cana-de-açúcar como único volumoso. Revista Brasileira de Zootecnia 31 (1), 444-450.

Caetano, L., Proposição de um sistema modificado para quantificação de biogás, 1985. 75 f. Dissertação (Mestrado em Agronomia/Energia na Agricultura) Faculdade de Ciências Agronômicas - Universidade Estadual Paulista, Botucatu.

Cavinato, C., Bolzonella, D., Pava, P., Fatone, F., Cecchi, F., 2013. Mesophilic and thermophilic anaerobic co-digestion of manure activated sludge and source sorted biomanure in pilot-and-full-scale reactors. Renewable Energy 55, 260265.

Cestonaro, T., Costa, M.S.S.de.M., Costa, L.A.de.M., Rozatti, M.A.T., Pereira, D.C., Lorin, H.E.F., Carneiro, L.J., 2015. The anaerobic co-digestion of sheep bedding and $\geqslant 50 \%$ cattle manure increases biogas production and improves biofertilizer quality. Waste Manage. 46, 612-618. http://dx.doi.org/10.1016/j. wasman.2015.08.040.

Comino, E., Rosso, M., Riggio, V., 2009. Development of a pilot scale anaerobic digester for biogas production from cow manure and whey mix. Bioresour. Technol. 100, 5072-5078.

Costa, M.S.S.de.M., 2005. Caracterização dos dejetos de novilhos superprecoces: reciclagem energética e de nutrientes. 126f. Tese (Doutorado em Energia na Agricultura) - Faculdade de Ciências Agronômicas, Universidade Estadual Paulista, Botucatu.

Costa, M.S.S.de.M., Costa, L.A.de.M., Lucas Jr., J.de., Pivetta, L.A., 2013. Potentials of biogas production from super young bulls manure fed with different diets. Engenharia Agrícola 33 (6), 1090-1098. 
de Vries, M., van Middelaar, C.E., de Boer, I.J.M., 2015. Comparing environmenta impacts of beef production systems: a review of life cycle assessments. Livestock Sci. 178, 279-288.

Ferreira, I.C., Silva, M.A., Barbosa, F.A., Carvalho, A.D.F., Correa, G.S.S., Fridrich, A.B. Souza, J.E.R., 2009. Avaliação técnica e econômica de diferentes grupos genéticos de bovinos de corte machos superprecoces e do sistema de produção em confinamento. Arq. Bras. Med. Vet. Zootec. 61 (1), 243-250.

González, L.A., Manteca, X., Calsamiglia, S., Schwartzkopf-Genswein, K.S., Ferret, A. 2012. Ruminal acidosis in feedlot cattle: interplay between feed ingredients, rumen function and feeding behavior (a review). Anim. Feed Sci. Technol. 172, 66-79.

Gou, C., Yang, Z., Huang, J., Wang, H., Xu, H., Wang, L., 2014. Effects of temperature and organic loading rate on the performance and microbial community of anaerobic co-digestion of manure activated sludge and food manure. Chemosphere 105, 146-151.

Gu, Y., Chen, X., Liu, Z., Zhou, X., Zhang, Y., 2014. Effect of inoculum sources on the anaerobic digestion of rice straw. Bioresour. Technol. 158, 149-155.

Hardoim, P.C., 1999. Efeito da temperatura de operação e da agitação mecânica na eficiência da biodigestão anaeróbia de dejetos de bovinos. $88 \mathrm{f}$. Tese (Doutorado em Produção Animal) - Faculdade de Ciências Agrárias e Veterinárias, Universidade Estadual Paulista, Jaboticabal.

Hidalgo, D., Martín-Marroquín, J.M., 2014. Effects of inoculum source and codigestion strategies on anaerobic digestion of residues generated in the treatment of manure vegetable oils. J. Environ. Manage. 142, 17-22.

Kinnunen, H.V., Koskinen, P.E.P., Rintala, J., 2014. Mesophilic and thermophilic anaerobic laboratory-scale digestion of nannochloropsis microalga residues. Bioresour. Technol. 155, 314-322.

Lovett, D., Lovell, S., Stack, L., Callan, J., Finlay, M., Conolly, J., O’Mara, F.P., 2003. Effect of forage/concentrate ratio and dietary coconut oil level on methane output and performance of finishing beef heifers. Livestock Prod. Sci. 84, 135146.

Mathot, M., Decruyenaere, V., Stilmant, D., Lamberta, R., 2012. Effect of cattle diet and manure storage conditions on carbon dioxide, methane and nitrous oxide emissions from tie-stall barns and stored solid manure. Agric. Ecosyst. Environ. 148, 134-144.

Malavolta, E., Vitti, G.C., Oliveira, S.A., 1989. Avaliação do estado nutricional das plantas: princípios e aplicações. Piracicaba. Associação Brasileira para Pesquisa da Potassa e do Fosfato, 193p.

Miranda, A.P., 2009. Suínos em diferentes fases de crescimento alimentados com milho ou sorgo: desempenho, digestibilidade e efeitos na biodigestão anaeróbia. 123 f. Tese (Doutorado em Zootecnia/Produção Animal) - Faculdade de Ciências Agrárias e Veterinárias - Universidade Estadual Paulista, Jaboticabal.

Miranda, A.P., Lucas Jr., J.de., Thomaz, M.C., Pereira, G.T., Fukayama, E.H., 2012 Anaerobic biodigestion of pigs feces in the initial, growing and finishing stages fed with diets formulated with corn or sorghum. Engenharia Agrícola 32 (1), 47-56.

NRC - National Research Council, 2001. Nutrient Requirements of Dairy Cattle, 7th ed. Washington.
Oaigen, R.P., Barcellos, J.O.J., Canozzi, M.E.A., Soares, J.C.dos.R., Canellas, L.C., Alves, C.O., Tavares, H.R. Costa, F.M.da., 2013. Competitividade inter-regional de sistemas de produção de bovinocultura de corte. Ciência Rural 43 (8), 14891495.

Ogino, A., Sommart, K., Subepang, S., Mitsumori, M., Hayashi, K., Yamashita, T., Tanaka, Y., 2015. Environmental impacts of extensive and intensive beef production systems in Thailand evaluated by life cycle assessment. J. Cleaner Prod. http://dx.doi.org/10.1016/j.jclepro.2015.08.110.

Orrico Jr., M.A.P. Orrico, A.C.A., Lucas Jr., J.de., 2009. Biodigestão anaeróbia de dejetos de suínos com e sem separação da fração sólida em diferentes tempos de retenção hidráulica. Engenharia Agrícola 29 (3), 474-482.

Orrico Jr., M.A.P., Orrico, A.C.A., Lucas Jr., J.de., 2010. Influência da relação volumoso: concentrado e do tempo de retenção hidráulica sob a biodigestão anaeróbia de dejetos de bovinos. Engenharia Agrícola 30 (3), 386-394.

Orrico Jr., M.A.P., Orrico, A.C.A., Lucas Jr., J.de., 2011. Produção animal e o meio ambiente: uma comparação entre potencial de emissão de metano dos dejetos e a quantidade de alimento produzido. Engenharia Agrícola 31 (2), 399-410.

Orrico Jr., M.A.P., Orrico, A.C.A., Lucas Jr., J.de., Sampaio, A.A.M., Fernandes, A.R.M., Oliveira, E.A.de., 2012. Biodigestão anaeróbia dos dejetos da bovinocultura de corte: influência do período, do genótipo e da dieta. Revista Brasileira de Zootecnia 41 (6), 1533-1538.

Pereira, P.M.R.C., Pinto, M.F., Abreu, U.G.P.de., Lara, J.A.F.de., 2009. Características de carcaça e qualidade de carne de novilhos superprecoces de três grupos genéticos. Pesquisa Agropecuária Brasileira 44 (11), 1520-1527.

Rubiano, G.A.G., Arrigoni, M.de.B., Martins, C.L., Rodrigues, E., Gonçalves, H.C., Angerami, C.N., 2009. Desempenho, características de carcaça e qualidade da carne de bovinos superprecoces das raças Canchim, Nelore e seus mestiços. Revista Brasileira de Zootecnia 38 (12), 2490-2498.

Saidu, M., Yuzir, A., Salim, M.R., Salmiati, Azman, S., Norhayati, A., 2013. Influence of palm oil mill effluent as inoculum on anaerobic digestion of cattle manure for biogas production. Bioresour. Technol. 141, 174-176.

Sakar, S., Yetilmezsoy, K., Kocak, E., 2009. Anaerobic digestion technology in poultry and livestock manure treatment - a literature review. Manure Manage. Res. 27, $3-18$.

Silva, D.J., Queiroz, A.C., 2002. Análise de alimentos: métodos químicos e biológicos, 3rd ed. Editora Universitária, Viçosa, MG, 166p.

Silveira, A.C., 1995. Sistema de produção de novilhos precoces. In: Encontro Nacional Sobre Produção De Novilhos Precoces. CATI, Anais, Campinas, 56p.

Souza, C.F., Lucas Jr., J.de., Ferreira, W.P.M., 2005. Biodigestão anaeróbia de dejetos de suínos sob efeito de três temperaturas e dois níveis de agitação do substrato: considerações sobre a partida. Engenharia Agrícola 25 (2), 530-539.

Torquato, C., Cabral, W.B., Vieira Júnior, L.C., 2012. Protocolos de adaptação de dietas com baixa e alta participação de concentrado sobre o desempenho de bovinos em confinamento. Revista eletrônica Nutritime - ISSN 1983-9006, Artigo 181, 9, 5, 2050-2074.

Van Soest, P.J., Robertson, J.B., Lewis, B.A., 1991. Methods for dietary fiber, neutral detergent fiber, and nonstarch polysaccharides in relation to animal nutrition. J. Dairy Sci. 74 (10), 3583. 